\title{
Multifunctional Backpack Without Spinal Disorder as a Portable Bag Massager for Chiropractic
}

\author{
Bella Naziel Iqmalia ${ }^{1}$, Lutfi Wicaksono ${ }^{2}$, M Subhan $^{3}$, Binti Mualifatul Rosydah ${ }^{4}$ \\ \{bellanazieliqmalia123@gmail.com¹utfiwicaksono3@gmail.com² \\ subhan.k3ppns@gmail.com³ binti.mualifatul@gmail.com ${ }^{4}$ \} \\ Teknik Keselamatan dan kesehatan Kerja, Politeknik Perkapalan Negeri Surabaya, Jalan \\ Teknik Kimia Kampus ITS Sukolilo, Surabaya, 60111 $1^{1-4}$
}

\begin{abstract}
Bags are very important equipment in life. According to the association of scoliosis care, more than $90 \%$ of people in developing countries reported using a backpack. Bag type backpack is very much an enthusiast in the era of globalization as it is today because the backpack is more practical and has a greater capacity. Although much in demand, the use of an unsuitable backpack in terms of design, heavy load, and how to use it has a considerable negative impact that it can increase the stress on the structure of the spine, back pain, changes in posture, and gait. If it is done continuously may result in irreversible changes, because the ligaments and spine degenerate with age. Spinal healing therapy that is widely applied all this time is chiropractic therapy. This study aims to design and make a multifunctional backpack without spinal disorder that can function as a support for chiropractic therapy. Research method using a cross sectional survey to study correlation dynamics between risk factors and effects, using approaching, observing or collecting data at a time (point time approach). This multifunctional backpack has been successfully designed and created by combining chiropractic device therapy. The results showed that this backpack proved to be comfortable and ergonomic when it was used.
\end{abstract}

Keywords: Backpack, Chiropractic, Massager

\section{Introduction}

A bag is one of the tools in carrying activity, which is a kind of manual material handling activities. Bags are widely used to bring books, stationery, and other purposes. In the United States, approximately 4 million children use backpacks to carry their goods. According to the association of scoliosis care, more than $90 \%$ of people in developing countries reported using a backpack. Backpacks are very interested in this globalization era, because more practical 
and have a larger capacity. Although much in demand, the use of an unsuitable backpack in terms of design, heavy load, and how to use it has a considerable negative impact that it can increase the stress on the structure of the spine, back pain, changes in posture, and gait, if it is done continuously may result in irreversible changes, because the ligaments and spine degenerate with age. Indonesian society culture while wearing the backpack often exceed the recommended weight. Heavy backpack load that recommended by the American Occupational Therapy Association (AOTA) and the America Academy of Pediatrics is 10\% to $15 \%$ of body weight. The heavier the backpack load causes emphasis on the disc, which has a function as a cushion between the bones in the spine. Spinal healing therapy that is widely applied all this time is chiropractic therapy. Chiropractic therapy can be applied in various forms of portable; one of them is applied in the form of bags that can be taken anywhere and practical. By combining a chiropractic therapy device using manual handling method and designing an appropriate backpack of anthropometry standards, generated multifunction backpack backbone anti-spine backpack that can be used as portable bag massager. This innovation is expected to provide a solution for backpack users and can help contribute therapeutic products in the world of health, especially in Indonesia. The first paragraph after a heading is not indented.

\section{Research Method}

Research method using a cross-sectional survey to study correlation dynamics between risk factors and effects, using approaches, observing, or collecting data at a time (point time approach). Field study is done by spreading the Nordic Body Map questionnaire and Interviewing. The literature review stage is done to study science theory about problemsolving found in the next stage. This stage also can be done whenever during the research process if the researcher needs another theory to support this research. The research questions are arranged after understanding the problems occurring and then formulate them according to the facts taken place in the field. The researcher uses two methods in the data collection. They are library research and field research. The stages of data collection using field research method are observation, interview, and documentation. Data collection needed in this research is complaints data based on nbm. Participants complain data is a research basis. The results of backpack design analysis generate an ergonomic suggestion about the multifunctional backpack. The advice is that the design of the backpack needs to be developed so that the creation of multifunctional backpack products by technological developments and product ideas must be increased to contribute other new things to the innovation of health equipment. After all of the hypotheses based on the analysis, the result is made, the conclusion of the research can be generated in the first paragraph after a heading is not indented.

\subsection{Design Making}

The technique of making this backpack is by forming a design pattern as in Figure 2. The product is made using a sewing machine with Cordura fabric base material. This backpack design tends to be like a design of a mountain bag or commonly called a carrier. Backpack load distribution is shown in figure 3. The goal is to reduce the risk of spinal disorders due to the use of a backpack. Then, the design of the back of the backpack by kneading massager system designed as a tool of chiropractic therapy. The system of using therapeutic devices on this backpack is divided into two, the automatic system and the system 
on /off button. Figure 4 shows the use of therapy using an automatic system. Whereas if you use the system on/off, the components used is a button located on the side of the backpack. Can be seen in Figure 5 is a flow diagram of the system on /off the backpack. When the user wants to use a therapeutic tool directly then just by pressing a button on, the therapy device will turn on and massaging her back and give the user a sense of warmth.

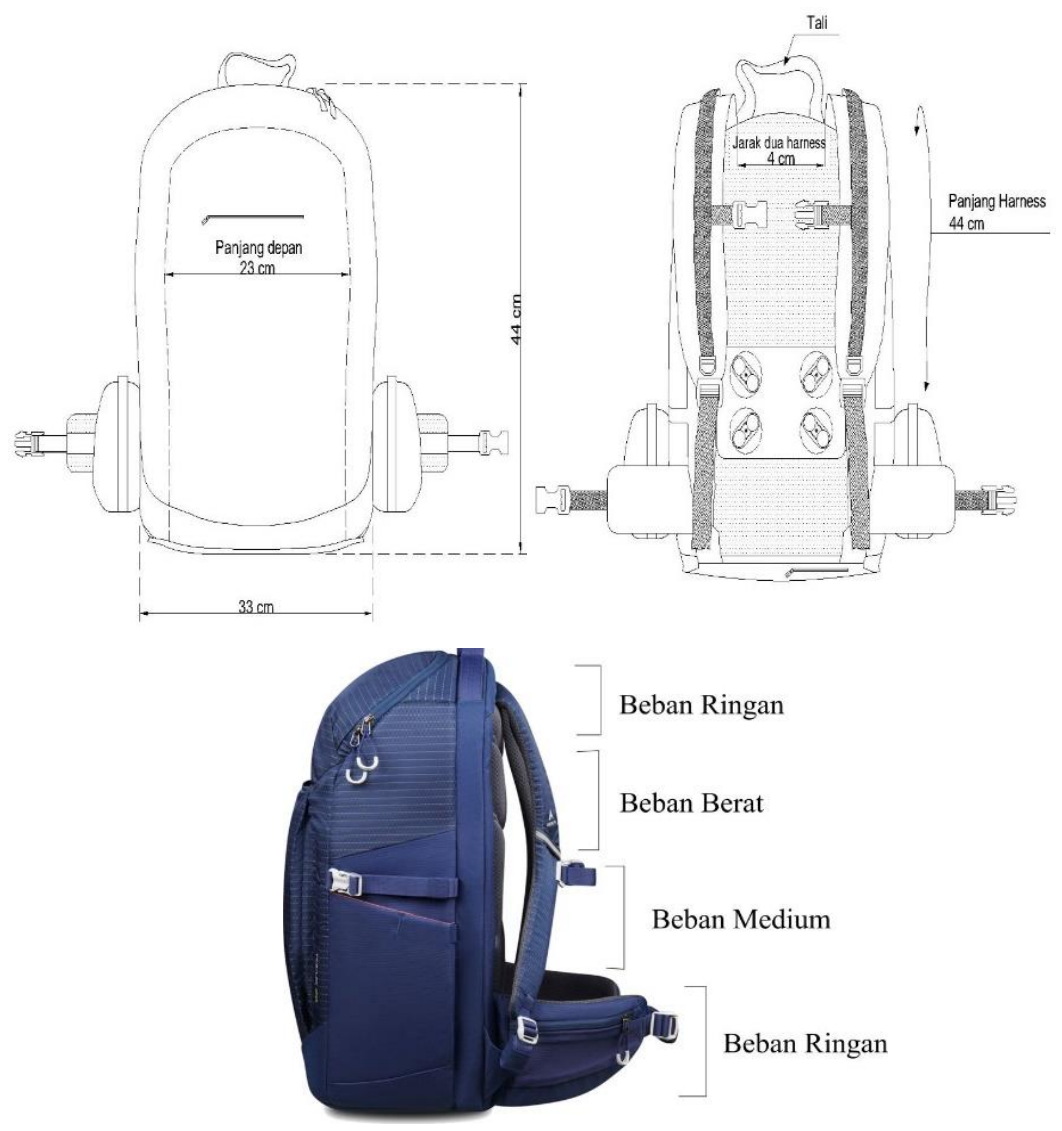

Fig 3. Backpack Load Distribution
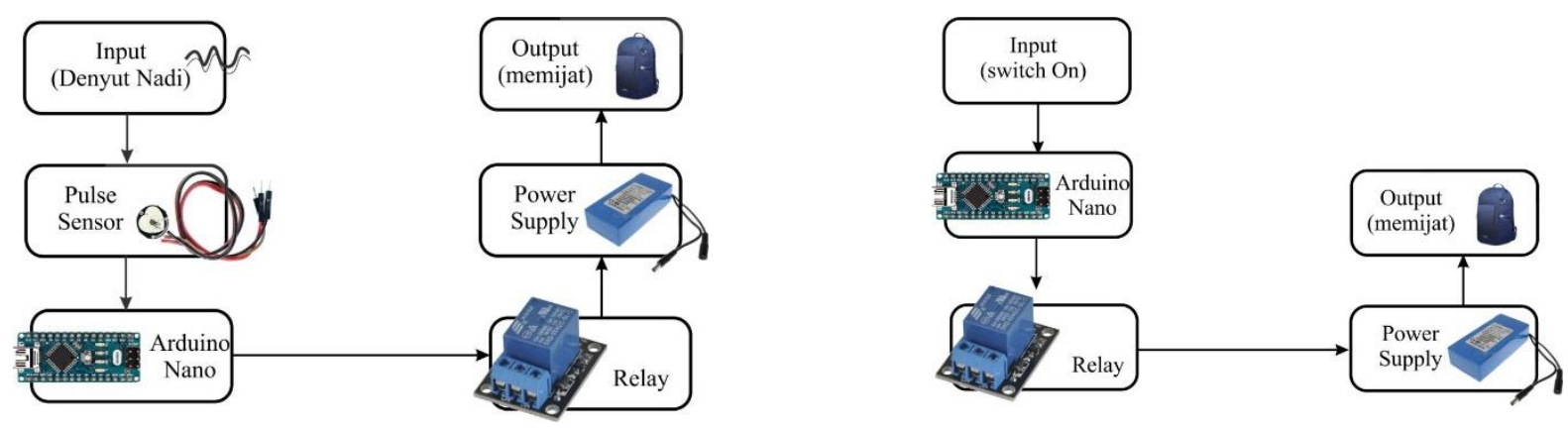
Fig 4. Flow Chart of Automatic System

Fig 5. Flow Chart of On/Off System

\subsection{Backpack Testing}

Backpack testing is carried out to determine the effectiveness of the performance on each component, whether it has functioned according to the expected use and purpose or not. The backpack testing process divided into two methods. The first method is using a Nordic Body Map questionnaire. Before data collection, backpacks that have been made by anthropometric standards 2017 will be compared with 10 other brand backpacks by wearing it to 10 respondents, each for 2 weeks. The result is a qualitative result about complaints of respondents for using this backpack or other brands. The second backpack testing is this backpack used by respondents vertebrate normal for one month with the rules one day for 30 minutes messages or when the back pain respondent fatigue. Furthermore, spine respondents would pass through an x-ray to determine the condition after using this backpack. The results obtained are of x-ray analysis of spinal medical experts and interviewing respondents about this backpack.

\section{Results and Discussions}

\subsection{Respondents Data Collection}

Data collection was carried out using Nordic Body Map questionnaire, which was distributed to 10 students at Shipbuilding Institute of Polytechnic Surabaya as research respondents. The following Table 1 are the names and data of respondents:

Table 1. Respondents Data of Nordic Body Map

\begin{tabular}{lll}
\hline Participant's name & Age (Years) & Backpack Brands \\
\hline Participant 1 & 23 & Backpack 1 \\
Participant 2 & 21 & Backpack 2 \\
Participant 3 & 22 & Backpack 3 \\
Participant 4 & 20 & Backpack 4 \\
Participant 5 & 18 & Backpack 5 \\
Participant 6 & 22 & Backpack 6 \\
Participant 7 & 24 & Backpack 7 \\
Participant 8 & 23 & Backpack 8 \\
Participant 9 & 21 & Backpack 9 \\
Participant 10 & 21 & Backpack 10 \\
\hline
\end{tabular}

\subsection{Data Processing of Nordic Body Map Questionnaire}

This study is a cross-sectional epidemiological study, meaning that the results obtained describe the conditions at a certain time. The epidemiological measure used is the point prevalence which can be defined as the level of equalization of back complaints in 10 research respondents. Prevalence obtained from the count of the ratio between the number of 
cases existing and new cases by the total number of people in the population. The following Figure 6 is the result calculation of prevalence frequency graph using the respondent's complaint data processing other brands backpacks. While Figure 7 is the result calculation of prevalence frequency graph using the respondent's complaint data processing other brands backpack.

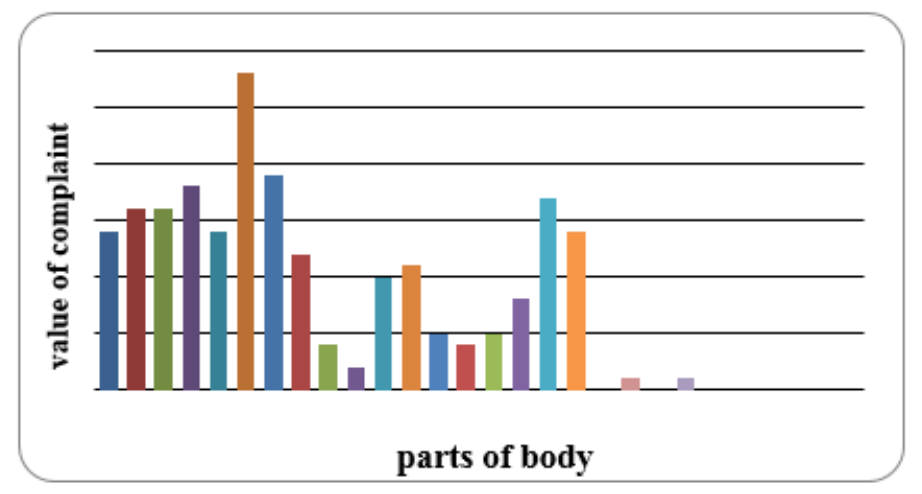

Fig. 6 Graph of Data Processing Complaints use Other Brands Backpacks

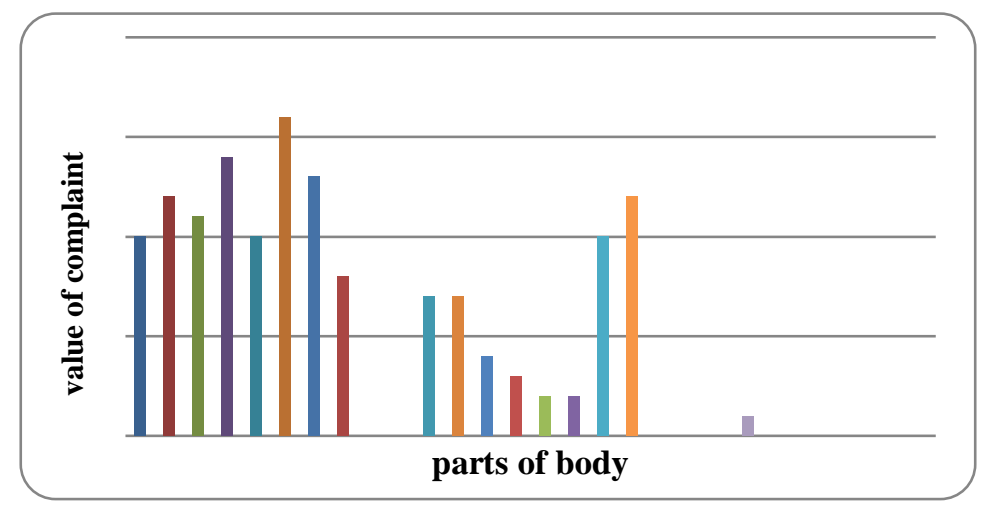

Fig. 7 Graph of Data Processing Complaints use this Backpacks

The results show that the 10 respondents gave a value of 28 or $93 \%$ of complaints in the back while using other brands backpack, while for this backpack respondents give 16 value or $56 \%$ of complaints on the back. This suggests that this backpack has been designed according to user ergonomics are raced on the data anthropometric by the Association of Anthropometric Indonesia in 2017. 


\subsection{Test using X-Ray}

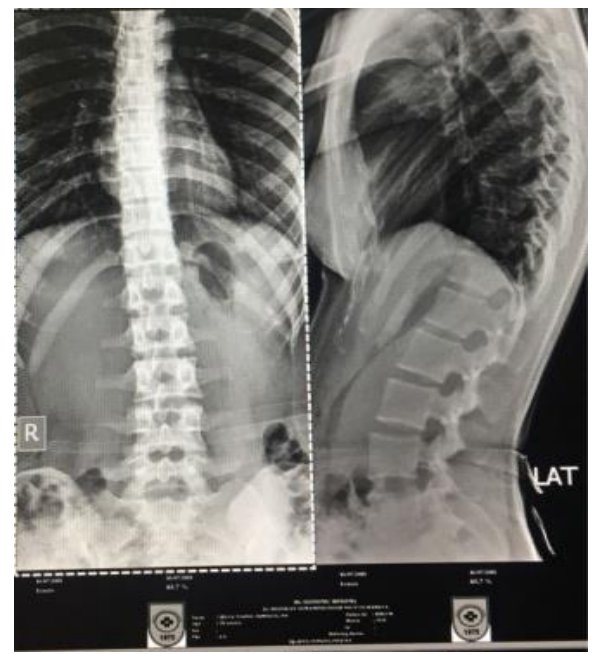

Fig 8. X-Ray Results

The second testing is the backpack used by respondents with normal vertebrate for one month with the use of a single day for 30 minutes or when the respondent spine ached with fatigue. Furthermore, the spine of respondents tested spine x-ray to determine the condition after using this backpack. The result is about an analysis of the images of x-ray conducted by the Hospital of the Mutual Cooperation by Dr.Carlo in Semampir Surabaya as spinal medical experts, he analyzed that the backpack does not harm the spinal respondents but can activate the muscle movements of the spine and reduce pain dorsally.

\section{Conclusions}

This multifunctional backpack has been successfully designed and created by combining chiropractic device therapy using manual handling methods and designing an appropriate backpack of anthropometry standards. To evaluate the ergonomic backpack side, an observation, interview, and documentation were carried out. This backpack is more effective than a backpack that has been existed because it is not just any backpack with many advantages as a backpack that has spine and back pain with the chiropractor method using kneading massager besides the presence of heat generator that is used for blood circulation. The specifications of this backpack are made of waterproof material, there is room for even loading, kneading massager, strip balance, and batik design that signifies the love of users with Indonesian backpack. This backpack has gone through 2 Nordic aesthetic tests using a body map test questionnaire and $\mathrm{x}$-ray testing on respondents. The results showed that this 
backpack proved to be comfortable and ergonomic when it was used and did not endanger the response but can activate muscle movements in the spine and reduce pain in the back.

Acknowledgments. The authors would like to thank our supervisor, Mrs. Binti Mualifatul Rosyidah, for their good support for research knowledge and consultation. The authors also want to thank the lecturers of other departments who have helped to make this backpack successful, namely Mr. Meidi, Mr. Hendro, and Mr. Adi and friends who supported this research.

\section{References}

[1] Ali, M: Strategi Penelitian Pendidikan. Bandung: Angkasa (1993)

[2] Bauer, D. H: A recommendation for the backpack load limit of middle school students based on physiological and psychophysical measurements: The pennsylvania state University. ProQues Dissertations and theses. (2007)

[3] Bull, E: Nyeri punggung (J. Surapsari, Terj.). Jakarta: Erlangga. (2005)

[4] Etra Fianus Hendri, Ari Pristiana Dewi, Darwin Karim. Hubungan Penggunaan Backpack dengan Kejadian Low Back Pain pada Mahasiswa Universitas Riau. JOM PSIK, 12 (2014)

[5] Janah, Diah : Jurnal Ekonomi. Analisis Ergonomi terhadap Rancangan Tas Backpack, pp 10 (2016)

[6] Mahadewa, Tjokorda, G.B, \& Maliyana,S: Diagnosis dan tatalaksanaan kegawatdaruratan tulang belakang. Jakarta: Sagung Seto. (2009)

[7] Nasir Widha Setyanto, R. Y Ergonomics Analysis in the Scarfing Process by OWAS, NIOSH and Nordic Body Map's Method at Slab Steel Plant's Division. IJIRSET 4(3) (2015)

[8] Nataya Charoonsri Rizani, Agie Satria:Identifikasi Kebutuhan Pelanggan Dalam Perancangan Dan Pengembangan Konsep Tas Backpack Yang Ergonomis Dan Multifungsi. Jurnal Teknik Industri Universitas Trisakti : Tugas Akhir (2013)

[9] Skaggs, D.L, Early, S.D, D Ambra, Tolo \& Kay Back pain and backpack in school children : Journal Of Pediatric Orthopedic. (2016)

[10] Sya'bani, D. P :Hubungan tingkat pengatahuan tentang backpack safety terhadap keluahan nyeri punggung pada siswa kelas 5 di kelurahan Tegalpanjang Garut. Diperoleh Pada Tanggal 22 Oktober 2013. Skripsi tidak di publikasikan (2012)

[11] Natural Healing Series-Natural Holistic Therapies for Common Ailments Overcoming Backache :. USA : Triden Reference Publishing (2005)

[12] "DHHS (NIOSH) Publication, Musculoskeletal Disorders and Workplace Factors : A Critical Review of Epidemiologic Evidence for Work-Related Musculoskeletal Disorders of the Neck, Upper Extremity, and Low Back", U.S. Department of Health And Human Services, ( 1997) 